\title{
LABOUR MARKet Reform AND POTENTIAL INEQUALITY of OUTCOMES: The Australian StORY
}

\author{
Alexis Esposto* \\ Faculty of Business and Enterprise, Swinburne University of Technology
}

\begin{abstract}
The global knowledge economy has transformed the world of work in the last four decades. Over the last 40 years the Australian economy underwent major structural change a phenomenon that was initiated in the United Kingdom and the United States in the 1980s. This paper discusses and analyses institutional change characterised by the decentralisation of collective bargaining structures that began in the early 1980s. The paper analyses the impact of these reforms by providing a simple analysis of job creation over a thirty year period. The paper concludes that institutional labour market change can at times produce negative welfare outcomes, particularly as it relates to employment creation. The impact of these effects is increasing inequality of earnings in the labour force.
\end{abstract}

Key words: labour market, institutional change, earnings and income inequality

JEL: J080, 210, 510

1

\section{The Australian labour market in context}

Since the mid-1970s nearly all OECD member countries, including Australia, have experienced fundamental economic and social change. These developments have manifested themselves in a variety of ways, including rapid technological change, the freeing up of capital markets, increased overseas trade and substantial changes to the labour market (Esposto \& Abbott, 2011; Esposto, 2008). Many economists and other social scientists have described these changes as the rise of the Global Knowledge Economy (GKE) (e.g. OECD, 1996; Houghton $\&$ Sheehan, 2000).

The global knowledge economy is emerging from two defining forces, namely, the rise in the knowledge intensity of economic activities, and the increasing globalisation of economic affairs. The rise in knowledge intensity is being driven by the combined forces of the information technology revolution, and the increasing pace of technological change. Globalisation, on the other hand, is being driven by national and international deregulation, transportation improvements and by the IT related communications revolution (Houghton, 2002). These forces are having a massive impact on nations, regions, firms, communities and individuals in the way in which they perform their daily activities and are required to adapt to such profound changes.

These changes can cause both polarisation and convergence of nations, regions, and communities economically and socially. Such polarisations manifest themselves in terms of increasing inequalities of income, earnings or wealth, not only between nations, but within and between regions, communities and individuals. Others argue that we are now experiencing a period of convergence and that poverty around the world has actually declined and is likely to continue over the foreseeable future, particularly as a result of the rapid economic growth of China, India, Brazil and Russia (e.g. Sala-i-Martin, 2006). The way nations such as Australia respond or tackle these challenges will be a major determinant of prosperity for the future. Since the mid-1970s nearly all OECD member countries, including Australia, have experienced fundamental economic and social change. These have manifested themselves in a variety of ways, including rapid technological change, freeing up of capital markets, increasing overseas trade and massive changes to the labour market. Throughout this period, and especially during the 1980s and the 1990s, the Australian labour 
market experienced persistent levels of high unemployment and increasing inequality in the distribution of earnings. At the same time there had been rapid growth in different types of employment (Esposto, 2008).

In light of these massive changes, this paper analyses the impact of these reforms by providing a simple analysis of job creation over a forty year period. The paper is thus divided as follows: section 1 provides an introduction; section 2 discusses changes in the Australian labour market; section 3 presents the various institutional reforms that occurred in Australia over the last three decades; section 4 examines labour market change over a 40 year period; section 5 analyses upskilling in employment growth and hours worked; and section 6 provided a discussion of results and conclusions.

\section{2}

\section{Changes in the Australian labour}

The Australian labour market has experienced enormous change over the last three decades. A major feature of this change has been the increasing diversity in the nature of work and the types of employment in which Australians are now engaged (VandenHeuvel \& Wooden, 2000). For example, up until the 1970 s, most Australians workers were in permanent fulltime employment. During the early 1970s, just over one in ten worked in part-time employment - defined by the ABS as employment that involves less than 35 hours per week. By 2002 nearly one in three employees were employed on a part-time basis. Furthermore, in the early 1980s, alternative work arrangements began to flourish, especially casual employment.

Two major factors have contributed towards a trend that promotes labour market change, namely, demand and supply factors, and institutional forces. The desire of many workers to combine responsibilities and personal interests with participation in the labour market has impacted the supply side. An example hereof is the entry of many women into the labour market who combine home responsibilities with employment arrangements like casual and parttime work. Similarly, students have become strong participants in the labour market by studying and working at the same time.
The increasing diversity of employment types in Australia has also been strongly influenced by demand factors. According to Dunlop (2002), many product markets have changed considerably as a result of globalisation and technological change.

This has generated a necessary response by firms to find ways to reduce costs and compete more efficiently in often increasingly volatile and uncertain markets ... Casual and part-time employment have provided opportunity for employers to do this (Dunlop, 2002:156).

Government policy has also encouraged a move towards labour market flexibility, achieved largely, amongst other things, through the spread of enterprise bargaining and a corresponding decline in compulsory conciliation and arbitration, which was a key feature of Australia's industrial relations landscape prior to the 1980s (Campbell \& Brosnan, 1999).

These changes implemented by government over the past two decades continued the trend towards increasing diversity of job types, particularly the rise in part-time and casual employment (e.g. VandenHeuvel \& Wooden, 2000).

Part-time and casual employment arrangements have taken a more prominent share of total employment, with a corresponding decline in the creation of permanent full-time employment (Esposto, 2011).

\section{3}

\section{Institutional change in Australia and abroad}

In Australia, New Zealand and the UK these changes in the labour market have been reflected in a corresponding institutional change characterised by the decentralisation of collective bargaining structures that began in the early 1980s (Wooden \& Sloan, 1998). More recently, the Australian government introduced further labour market deregulation in the form of legislation known as Australian Workplace Agreements. A common feature of these countries was that, in relative terms, they had reasonable levels of union participation in their workforce, and trade unions played an important role in negotiating wages outcomes 
for their members, as well as in national policy matters. The UK began the process of transforming industrial relations after the election of the Thatcher government in 1979. The government's strategy was to introduce a variety of laws which transformed the industrial landscape. The salient features of this process were the decentralisation of pay determination, the growth of plant and individual bargaining, and the decline in industrial action by unions and their membership (Wooden \& Sloan, 1998:197). The changes in New Zealand were far more dramatic, beginning with the Employment Contracts Act in 1991. This had the effect of accelerating the process of change with the abolition of the award system, and trade unions losing a large number of industrial and legal rights (Wooden \& Sloan, 1998:198). Changes to the industrial relations system in Australia did not occur with the same severity and speed. According to Campbell and Brosnan (1999) there was gradual but fundamental process of labour market deregulation, characterised by 'slow combustion rather than Big Bang [the New Zealand experience], and it continues to splutter and send out sparks' (Campbell \& Bronsnan, 1999:354). However, the changes have been of a fundamental nature, particularly in the way in which labour relations have been altered.

\section{What were the main changes to the industrial relations landscape in Australia?}

Wooden (2001) summarises five salient features of the major changes that have occurred in the Australian industrial relations system over the last 20 years. The first relates to the spread of enterprise bargaining. The distinctive feature of the system was compulsory conciliation and arbitration, characterised by independent quasijudicial industrial tribunals that had the power to stipulate legally binding awards that were required to be arbitrated or certified by these tribunals (Campbell \& Brosnan, 1999:354). This situation has changed considerably whereby most of the bargaining occurs at the enterprise level and the majority of the awards provide a starting point from which wages and other employment conditions are negotiated (Wooden, 2001:244). A second significant feature concerns the role that trade unions now have in the bargaining process of wage determination and employment conditions. Before 1993, the majority of industrial agreements would have required union participation. A third significant change has been the introduction of legislation (Australia Government, 1996) that gives employers the flexibility to use individually negotiated employment agreements that can either supplement and/or replace existing awards. Changes to the role of industrial tribunals have also been a significant aspect of labour market deregulation, much of which has been designed to diminish their significance and power. Furthermore, the role of the Australian Industrial Relations Commission (AIRC) in the arbitration of disputes has been reduced considerably, in the sense that it no longer has the power to impose arbitrated awards, and has been confined to disputes that relate to matters of awards and where the operation of essential services is in jeopardy (Wooden, 2001:247). Finally, the changing nature of industrial relations has impacted significantly on union membership. Since the 1970s the proportion of employees who are members of a trade union has fallen by 19 percentage points (Hawke \& Wooden, 1998: 76). Whether this is entirely due to changes in industrial relations is difficult to ascertain. It is possible to argue that much of the decline in union participation has been due to changes in the composition of employment that favoured industries that would employ a traditionally non-unionised workforce, rather than changes to the industrial relations system:

the most important changes ... being the shifts in the industrial structure of employment, the relative decline in public sector employment and the relative growth of casual employment. Our best guess is that the net effect of structural change was to reduce the overall unionization between 1982 and 1996 by somewhere between 40 and 45 per cent. (Hawke \& Wooden, 1998:79)

In summary, the Australian experience centres around the fact that enterprise bargaining is in the process of replacing arbitration as the dominant industrial relations paradigm, with employers and employees now expected to negotiate their working conditions and productivity. These changes also form part of 
similar processes of deregulation of labour markets around the world, resulting from the emergence of the GKE.

\section{Recent changes: The Fair Work Act of 2011}

The Fair Work Act commenced on 1 July 2009 , commencing a new period of industrial relations in Australia, as a response to the unpopular era of industrial relations in Australia (ACTU, 2011). This new legislation replaced the unpopular WorkChoices legislation, which was a catalyst for the election loss of the Howard government in 2007.

The changes introduced by the Fair Work Act aimed at restoring workers rights at work and included the following:

- no more Australian Workplace Agreement individual contracts;

- a strong safety net through the National Employment Standards; Collective bargaining rights, including a requirement to bargain in good faith;

- rights to union membership and representation;

- protection from unfair dismissal; and

- a genuine independent umpire to resolve disputes (ACTU, 2011).

While these changes were designed to cushion the increasing inequality of outcomes, an analysis of labour market change between 1971 to 2011 indicates that it has shown strong signs of polarisation of labour market outcomes.

\section{4}

\section{Labour market change and inequality of outcomes}

The changes discussed above have had a major impact on labour market outcomes in Australia. Table1 analyses total employment disaggregated to include changes for men and women in full-time and part-time work. Fulltime employment for men exhibits strong signs of upskilling in terms of job creation with increases in the demand for skills occurring in the top two skills categories, where the shares grew by 10.7 and 2.6 per cent, respectively. All other skills categories fell, not only in terms of shares. The lowest skills level, skills $\mathrm{V}$ experienced a pronounced fall in employment. Full-time female employment exhibited the same trend in terms of employment shares as full-time male employment. Employment creation also declined in the lowest skills category.

In terms of part-time jobs, employment growth occurred in all of the five skills categories for men and women. These changes were very strong ranging from 930 to 393 per cent in jobs created for men and women. However, part-time employment growth for men showed clear signs of deskilling. This can be seen by the decline in demand for skilled occupations and vocations (skills levels I, II and III) and increases in demand for lowskilled jobs (skills levels IV and V). Women experienced a mixed pattern of skills level changes, favouring upskilling as shown by the growth in employment for managers and professionals (skill I) and the share growth in skills level I.

These trends in upskilling reported in Table 1 indicate that over the long term the Australian labour market has shown clear signs of upskilling in full-time employment for males and females. Similarly, there are strong signs of upskilling in part-time employment for women, but these are not as pronounced as those found in full-time work. Conversely, for male part-time employment, the trends in employment growth show a clear pattern of deskilling.

\section{5}

\section{Upskilling in employment growth and hours worked}

This section extends the analysis carried out above by replicating the work of Wooden (2000), looking at changes both in occupational employment and in the occupational composition of hours worked between 1989 and 2009. The reason for conducting an analysis of hours worked is to ensure that labour demand is measured more accurately, particularly across different types of occupations. For example, average hours worked in managerial and professional occupations tend to be higher than in lower skilled occupations. This is because people in these positions tend to work longer hours without pay. In the case of lower skilled 
occupations such as sales and services, hours worked tend to be smaller because of the high incidence of part-time employment.

Table 1

Change in share for full-time and part-time male and female employees by skills level, 1971-2011

\begin{tabular}{|c|c|c|c|c|}
\hline Skill Level & 1971 & 2011 & $\begin{array}{l}\text { Employment } \\
\text { growth (\%) }\end{array}$ & $\begin{array}{c}\text { Change in share } \\
(\%)\end{array}$ \\
\hline Males & \multicolumn{4}{|c|}{ Full-time employees ('000s) } \\
\hline I Managers/Professionals & 649.8 & 1294.3 & 99.2 & 10.7 \\
\hline II Associate Professionals & 343.8 & 557.2 & 62.1 & 2.6 \\
\hline III Skilled vocations & 832.6 & 934.8 & 12.3 & -3.7 \\
\hline IV Intermediate skills & 790.8 & 882.3 & 11.6 & -3.7 \\
\hline V Elementary skills & 559.3 & 488.7 & -12.6 & -5.9 \\
\hline Total & 3176.3 & 4157.2 & 30.9 & \\
\hline Females & \multicolumn{4}{|c|}{ Full-time employees ('000s) } \\
\hline I Managers/Professionals & 161.5 & 811.4 & 402.4 & 21.3 \\
\hline II Associate Professionals & 98.3 & 366.2 & 272.5 & 7.4 \\
\hline III Skilled vocations & 175.1 & 215.2 & 22.9 & -5.8 \\
\hline IV Intermediate skills & 415.9 & 638.1 & 53.4 & -8.2 \\
\hline V Elementary skills & 305.4 & 270.9 & -11.3 & -14.6 \\
\hline Total & 1156.2 & 2301.8 & 99.1 & \\
\hline Males & \multicolumn{4}{|c|}{ Part-time employees ('000s) } \\
\hline I Managers/Professionals & 44.3 & 223.6 & 404.7 & -8.8 \\
\hline II Associate Professionals & 14.6 & 94.7 & 548.3 & -1.0 \\
\hline III Skilled vocations & 26.3 & 172.6 & 556.4 & -1.6 \\
\hline IV Intermediate skills & 33.3 & 261.8 & 686.3 & 1.9 \\
\hline V Elementary skills & 34.4 & 354.5 & 930.4 & 9.5 \\
\hline Total & 152.9 & 1107.2 & 624.1 & \\
\hline Females & \multicolumn{4}{|c|}{ Part-time employees ('000s) } \\
\hline I Managers/Professionals & 58.3 & 523.1 & 797.3 & 6.9 \\
\hline II Associate Professionals & 30.2 & 193.1 & 539.3 & 0.2 \\
\hline III Skilled vocations & 41.4 & 204.2 & 393.3 & -2.3 \\
\hline IV Intermediate skills & 110.8 & 733.5 & 562.0 & 2.0 \\
\hline V Elementary skills & 133.6 & 670.5 & 401.9 & -6.8 \\
\hline Total & 374.4 & 2324.4 & 520.8 & \\
\hline
\end{tabular}

Source: ABS census employment data for 1971. Occupations are aggregated to ASCO $2^{\text {nd }}$ edition major group. 'Inadequately described' and 'not stated' are not included in calculations. Estimates for 2011 are author's calculations based on least square estimates.

\section{'Casual' and 'permanent' employees}

In the light of the enormous growth in casual employment it is important, in the context of this paper, to consider its definition and nature. Casual employment has been defined differently by the Australian arbitration award system, in common law, and by the Australian Bureau of Statistics. The employment relationship which employees and employers enter into in Australia is governed by the award system. In the majority of awards, the term 'casual employment' is poorly defined. As pointed out by Owens (2001), the most significant attribute of a contract of employment for casual work is that the law sees each contract as separate (Owens 2001:120). Furthermore, there are two major features that highlight the difference between casual and permanent employment. The first is that each casual employment contract is treated as being unique in itself, and the second distinction is to be found in length of time provided in notices of termination. This can be found in the common law definition of casual work, which is summarised by Brooks (1985). Each engagement of a casual worker constitutes a separate contract of employment, and we can safely summarise the common law by saying that the only 
distinction of substance between the casual/ part-time employee and the full-time/ permanent employee lies in the period of notice required to properly terminate the contract (Brooks, 1985:166).

Thus, according to the common law definition, casual employment contracts provide employees and employers with the flexibility of termination at short notice. In other words, whereas permanent employees enjoy a minimum period of notice of termination (at least one week), casual employees may not be given notice of termination, and may not always be required to be re-engaged once their contracts expire (Burgess and Campbell, 1998b:36).

According to Dawkins and Norris (1990), another complexity can be found in the system of arbitral awards, wherein definitions of casual employment can vary considerably both within an industry and between different industries. It is evident that the common law definition is unable to capture all the characteristics of casual employment within specific or individualised contracts. Because of this, many researchers regard casual employment as being a negative type, or a 'substandard' form of employment, emphasising the fact that the majority of these jobs are characterised by low pay, limited opportunities for career progression, lack of provision for training, low levels of union representation, reduction in employee influence over decision making in the workplace, increase in insecurity regarding the future of jobs, and diminished employee entitlements, such as lack of parental leave entitlements for long-term casuals (e.g. Burgess \& Campbell, 1998a; ACIRRT, 1999; Watts, 2001; Campbell \& Burgess, 2001).

For all the inconsistencies in definition and shortcomings in effects for the employees concerned, casual, part-time and fixed term employment have a number of positive attributes. For example, an analysis of the Australian Workplace Industrial Relations Survey (AWIRS) which was conducted by Wooden (2001) shows that casual and fixed term employment have both positive and negative traits. Both permanent part-time and casual employees reported satisfaction with their jobs. Casual and part-time employees also reported lower levels of stress compared with their permanent counterparts. Significantly, permanent part-time employees reported high levels of satisfaction, which can be attributed to a higher average hourly rate of pay. Interestingly perhaps, this group did not appear to be preoccupied about job insecurity. Wooden also found that workers on fixed term contracts were more likely to report having influence over decision making, experienced lower stress levels and believed that they received reasonable payment for their work. They often also believed that their employers were likely to provide them with training opportunities (Wooden, 2001).

A different definition is provided by the ABS, which defines 'casual' employees as those who were entitled to neither paid holiday leave or paid sick leave, or both, in their main job'. In contrast, 'permanent employees' are defined as 'employees who were entitled to paid holiday leave or sick leave in their main job' (ABS cat. no. 6310.0:2002). According to Wooden and Warren (2003), the ABS definition has a number of limitations. Firstly, like most surveys, it has reporting deficiencies. For example, respondents may confuse the actual receipt of entitlements with access to entitlements and may, as a result, make a reporting error. Secondly many respondents may not be able to report information about leave entitlements, in which case the ABS may code these answers as being negative, and may as a consequence inflate the incidence of casual employees. Thirdly, the ABS definition of an employee includes owner-managers. Many owner-managers who respond to the ABS survey may say that they do not provide themselves with either sick leave or paid annual leave entitlements, and may be overstating the number of casual employees (see also for example, Murtough \& Waite, 2000; Campbell and Burgess, 2001, for a more detailed discussion). Finally, the ABS survey categorises all employees as either casual or permanent without making provision for those who are on fixed term contracts. Most of these are entitled to paid sick and annual leave, and as a result they may be assigned to the criteria of permanent employment status in the survey (Campbell \& Burgess, 2001:89). In spite of these limitations, the ABS survey is extremely valuable in the analysis of labour market 
change. It is historical in perspective, it allows researchers and policy makers to trace how the pattern of casual and permanent employment has changed over time, and it provides much information related to the incidence, characteristics and profile of the casual employment labour market.

Table 2 shows the growth in employment for men in full-time permanent and casual employment. The changes in employment show clear signs of polarization when comparing employment creation in permanent and casual work. The striking features of these changes are revealed in the share changes. In permanent employment it can be seen that employment growth has shown clear signs of upskilling, where the share growth in the number of persons and hours worked grew in the top three skills levels, but declined in skills IV and V.

Table 2

Growth in male permanent and casual full-time employment and aggregate hours worked per week by skills level category, August 1989 to August 2009

\begin{tabular}{|c|c|c|c|c|c|c|c|c|}
\hline Skills Category & \multicolumn{2}{|c|}{ Employment (000s) } & \multicolumn{2}{|c|}{$\begin{array}{c}\text { Aggregate } \\
\text { hours } \\
\text { (millions) }\end{array}$} & \multicolumn{2}{|c|}{$\begin{array}{c}\text { Net change } \\
(\%)\end{array}$} & \multicolumn{2}{|c|}{$\begin{array}{c}\text { Share change } \\
(\%)\end{array}$} \\
\hline \multicolumn{9}{|c|}{ Male permanent full-time } \\
\hline & 1989 & 2011 & 1989 & 2011 & Persons & Hours & Persons & Hours \\
\hline I Managers/Professionals & 707.8 & $1,136.6$ & 30.6 & 50.4 & 60.6 & 64.8 & 9.5 & 8.6 \\
\hline II Associate Professionals & 381.8 & 478.9 & 15.9 & 21.5 & 25.4 & 35.4 & 1.4 & 1.5 \\
\hline III Skilled vocations & 846.2 & 754.0 & 32.9 & 31.7 & -10.9 & -3.6 & -5.4 & -5.1 \\
\hline IV Intermediate skills & 755.8 & 823.0 & 30.2 & 35.9 & 8.9 & 18.9 & -0.7 & -0.3 \\
\hline V Elementary skills & 510.2 & 398.5 & 20.1 & 16.8 & -21.9 & -16.6 & -4.8 & -4.8 \\
\hline Total & 3201.8 & 3591.0 & 129.6 & 156.3 & 12.2 & 20.6 & & \\
\hline \multicolumn{9}{|c|}{ Male casual full-time } \\
\hline & 1989 & 2011 & 1989 & 2011 & Persons & Hours & Persons & Hours \\
\hline I Managers/Professionals & 49.3 & 53.9 & 2.5 & 2.3 & 9.3 & -9.1 & -8.3 & -11.6 \\
\hline II Associate Professionals & 23.9 & 32.5 & 1.2 & 1.4 & 35.8 & 17.2 & -2.5 & -3.9 \\
\hline III Skilled vocations & 62.5 & 98.8 & 2.6 & 4.5 & 58.1 & 74.8 & -3.3 & -0.2 \\
\hline IV Intermediate skills & 52.8 & 137.6 & 2.3 & 6.0 & 160.7 & 158.7 & 10.1 & 10.4 \\
\hline V Elementary skills & 45.9 & 99.4 & 1.8 & 4.1 & 116.6 & 128.4 & 4.0 & 5.2 \\
\hline Total & 234.3 & 422.2 & 10.4 & 18.3 & 80.2 & 75.8 & & \\
\hline
\end{tabular}

Source: ABS cat. no. 6310.0, 1989 and 2011 issues. Disaggregated data provided by the ABS. Estimates for 1989 derived by applying concordance weights as per Esposto's methodology (2008:110-113). Author's calculations.

For casual full-time work, the growth pattern is reversed indicating clear sings of downskilling. This is manifested by growth in the share of employment in the bottom two skills levels and declines in the share of employment growth in terms of persons and hours worked in the top three skills levels.

For women the changes are not too dissimilar to those experienced by men in fulltime work. In full-time permanent employment, women experienced clear signs of upskilling of employment outcomes, whereas in casual work, the experience was more uneven. The share change experienced no change in skills level I, there was a decline in skills level II and it fell for skills level V. These findings clearly show that job creation in Australia is biased towards occupations that are of a permanent nature in full-time work, but not in casual fulltime work, indicating clear signs of polarisation of employment outcomes. These changes may be interpreted as increasing inequalities of employment outcomes.

\section{Upskilling in job types: permanent and casual part-time employment}

Table 2 shows changes in the share of aggregate hours and employment in part-time work. The demand for male part-time permanent employment declined in terms of total hours worked, indicating clear signs of deskilling, especially in total hours worked. This trend 
was more pronounced in part-time work for men, where the demand for work declined in terms of persons and hours worked. Part-time employment for women experienced skills- bias in the demand for labour in permanent work and strong signs of polarization in casual part-time employment.

\section{Table 3}

Growth in permanent and casual female full-time employment and aggregate hours worked per week by skills level category, August 1989 to August 2011

\begin{tabular}{|c|c|c|c|c|c|c|c|c|}
\hline Skills Category & \multicolumn{2}{|c|}{ Employment (000s) } & \multicolumn{2}{|c|}{$\begin{array}{l}\text { Aggregate hours } \\
\text { (millions) }\end{array}$} & \multicolumn{2}{|c|}{$\begin{array}{c}\text { Net change } \\
(\%)\end{array}$} & \multicolumn{2}{|c|}{$\begin{array}{c}\text { Share change } \\
(\%)\end{array}$} \\
\hline \multicolumn{9}{|c|}{ Female permanent full-time } \\
\hline & 1989 & 2011 & 1989 & 2011 & Persons & Hours & Persons & Hours \\
\hline I Managers/Professionals & 350.3 & 872.5 & 13.4 & 37.1 & 149.1 & 176.9 & 18.6 & 17.8 \\
\hline II Associate Professionals & 152.6 & 308.9 & 5.9 & 12.6 & 102.4 & 113.8 & 4.2 & 3.7 \\
\hline III Skilled vocations & 296.6 & 176.8 & 10.7 & 7.1 & -40.4 & -33.6 & -11.0 & -10.6 \\
\hline IV Intermediate skills & 468.5 & 631.8 & 17 & 25.3 & 34.8 & 49.0 & -1.9 & -1.4 \\
\hline V Elementary skills & 306.2 & 222.0 & 11.1 & 8.7 & -27.5 & -21.7 & -9.9 & -9.5 \\
\hline Total & 1574.2 & 2211.9 & 58.1 & 90.8 & 40.5 & 56.4 & & \\
\hline \multicolumn{9}{|c|}{ Female casual full-time } \\
\hline & 1989 & 2011 & 1989 & 2011 & Persons & Hours & Persons & Hours \\
\hline I Managers/Professionals & 15.8 & 31.1 & 0.6 & 1.3 & 96.6 & 112.0 & -1.0 & 0.0 \\
\hline II Associate Professionals & 11.4 & 17.3 & 0.6 & 0.7 & 51.6 & 23.7 & -3.5 & -7.1 \\
\hline III Skilled vocations & 13.5 & 9.9 & 0.5 & 0.4 & -27.0 & -15.2 & -9.8 & -8.6 \\
\hline IV Intermediate skills & 22.4 & 76.9 & 0.8 & 3.0 & 243.1 & 271.0 & 16.4 & 17.1 \\
\hline V Elementary skills & 26.1 & 50.2 & 1 & 2.0 & 92.5 & 101.4 & -2.1 & -1.4 \\
\hline Total & 89.2 & 185.3 & 3.5 & 7.4 & 107.7 & 112.0 & & \\
\hline
\end{tabular}

Source: ABS cat. no. 6310.0, 1989 and 2011 issues. Disaggregated data provided by the ABS. Estimates for 1989 derived by applying concordance weights as per Esposto's methodology (2008, pp. 110-113). Author's calculations.

Table 4

Growth in employment and aggregate hours worked per week by skills level for male and female permanent and casual part-time employment, August 1989 to August 2011

\begin{tabular}{|c|c|c|c|c|c|c|c|c|}
\hline & \multirow{2}{*}{\multicolumn{2}{|c|}{$\begin{array}{c}\text { Net Change } \\
(\%)\end{array}$}} & \multirow{2}{*}{\multicolumn{2}{|c|}{$\begin{array}{c}\text { Share Change } \\
(\%)\end{array}$}} & \multirow{2}{*}{\multicolumn{2}{|c|}{$\begin{array}{c}\text { Net Change } \\
(\%)\end{array}$}} & \multirow{2}{*}{\multicolumn{2}{|c|}{$\begin{array}{c}\text { Share Change } \\
(\%)\end{array}$}} \\
\hline & & & & & & & & \\
\hline & \multicolumn{4}{|c|}{ Male permanent part-time } & \multicolumn{4}{|c|}{ Male casual part-time } \\
\hline & Persons & Hours & Persons & Hours & Persons & Hours & Persons & Hours \\
\hline I Managers/Professionals & 464.3 & 353.7 & 4.8 & -1.4 & 134.3 & 156.7 & -0.7 & -0.9 \\
\hline II Associate Professionals & 254.5 & 214.6 & 0.9 & -4.8 & 2.0 & 38.8 & -7.7 & -5.6 \\
\hline III Skilled vocations & 345.3 & 341.2 & 0.5 & -0.9 & 35.1 & 65.4 & -5.6 & -5.9 \\
\hline IV Intermediate skills & 485.5 & 499.9 & -2.3 & 5.6 & 190.9 & 254.6 & 4.0 & 6.8 \\
\hline V Elementary skills & 401.3 & 404.1 & -4.0 & 1.5 & 213.4 & 221.5 & 10.1 & 5.7 \\
\hline \multirow[t]{3}{*}{ Total } & 409.6 & 376.4 & - & - & 151.8 & 181.4 & - & - \\
\hline & \multicolumn{4}{|c|}{ Female permanent part-time } & \multicolumn{4}{|c|}{ Female casual part-time } \\
\hline & Persons & Hours & Persons & Hours & Persons & Hours & Persons & Hours \\
\hline I Managers/Professionals & 280.4 & 339.9 & 9.3 & 9.8 & 278.0 & 261.2 & 6.9 & 6.0 \\
\hline II Associate Professionals & 119.5 & 166.3 & -1.8 & -1.3 & -42.7 & -39.6 & -7.2 & -8.8 \\
\hline III Skilled vocations & 46.9 & 59.4 & -6.3 & -6.8 & -36.8 & -36.5 & -8.0 & -9.8 \\
\hline IV Intermediate skills & 256.4 & 309.1 & 9.5 & 10.1 & 101.8 & 146.6 & 8.6 & 11.5 \\
\hline V Elementary skills & 69.9 & 82.1 & -10.7 & -11.8 & 54.6 & 78.1 & -0.2 & 1.0 \\
\hline Total & 166.5 & 203.0 & 9.3 & 9.8 & 55.3 & 73.9 & - & - \\
\hline
\end{tabular}

Source: ABS cat. no. 6310.0, 1989 and 2011 issues. Disaggregated data provided by the ABS. Estimates for 1989 derived by applying concordance weights as per Esposto's methodology (2008, pp. 110-113). Author's calculations. 
6

\section{Conclusion}

Two main conclusions are arrived at in this study. The first is that the Australian labour market exhibited strong signs of upskilling in terms of occupational growth in aggregate over the long term (i.e. between 1971 and 2011). Upskilling was also detected when the analysis focused on job types. When occupations were disaggregated into full-time and part-time male and female employees, different trends were observed in different job types. There were very strong signs of upskilling in male and female full-time jobs, where the labour market exhibited strong growth in employment in highly skilled occupations and declines in lowskilled occupations. In terms of part-time employment, there were strong signs of deskilling for men, whereas women experienced upskilling trends.

The second conclusion is that over the period of 1989-2011, the patterns of upskilling are mixed for different job types in terms of total employment and total hours worked. Permanent male and female full-time employment exhibited clear signs of upskilling both in terms of employment growth and hours worked but this was not the case in casual fulltime work for men and women. Women in part-time work experienced upskilling trends in permanent work and polarisation in casual employment. Men, on the other hand, indicated clear signs of downskilling in terms of permanent and casual part-time work. The implication of these changes can be regarded as serious, given that potentially they are likely to create greater levels of inequality in the labour market. Thus, it is concluded to ensure that heavy institutional reform towards liberalization of the labour market has had a negative result in terms of labour market outcomes.

Furthermore, the changes described in this section reveal that Australia may be experiencing a different scenario of the Skill Bias Technical Change (SBTC) hypothesis. It is clear that if wages are inflexible downwards in the Australian labour market, but there exists a flexibility of job types (i.e. full-time and parttime permanent employment, and full-time and part-time casual employment, including fixed term employment), one way in which employers may reduce wage costs is by opting to employ workers on a part-time or casual basis. So, if wages are inflexible downwards (i.e. there exists a minimum wage protection scheme regulated by government) but the type of job creation is flexible in nature and this provides a lower cost alternative to employers, then this links to the SBTC hypothesis and job types. This may explain the rise and concentration in employment creation at the very top (e.g. as in the case of most skilled occupations or individuals) which is accompanied by increasing wages, whilst at the same time we see a decline in permanent full-time employment creation from the middle to the bottom of the employment distribution. This decline is then evidenced in a corresponding increase in parttime and casual employment creation occurring from the middle to the bottom of these types of employment distributions.

\section{Acknowledgement}

The authors are grateful to the valuable comments made by the reviewers.

*CORRESPONDING AUTHOR CONTACT

Alexis Esposto, aesposto@,swin.edu.au

\section{References}

AUSTRALIAN BUREAU OF STATISTICS (ABS). 1986. Australian standard classification of occupations/classification and classified list of occupations: Link file, cat. no. 2199.0, Canberra.

AUSTRALIAN COUNCIL OF TRADE UNIONS (ACTU). 2011. The Fair Work Act: two years on: A review of labor's changes to workplace laws. Available at: http://www.actu.org.au/images/dynamic/ attachments/7201/the_fair_work_act_two-years_on.pdf [accessed 2013-07-01]. 
AUSTRALIAN GOVERNMENT. 1996. Workplace Relations Act, Canberra. Available at: http://www. comlaw.gov.au/Details/C2006C00104 [accessed 2013-07-02].

BROOKS, B. 1985. Aspects of casual and part-time employment. Journal of Industrial Relations, June, 27:158-177.

CAMPBELL, I. \& BROSNAN, P. 1999. Labour market deregulation in Australia: The slow combustion approach to workplace change, International Review of Applied Economics, 13(3):353-394.

BURGESS, J. \& CAMPBELL, I. 1998a. The nature and dimensions of precarious employment in Australia, Labour and Industry, 9(1):31-54.

BURGESS, J. \& CAMPBELL, I. 1998b. Casual employment in Australia: growth, characteristics, a bridge or a trap? Economic and Labour Relations Review, June, 9:31-54.

CAMPBELL, I. \& BURGESS, J. 2001. A new estimate of casual employment. Australian Bulletin of Labour, 2(2):85-108.

DAWKINS, P. \& NORRIS, K. 1990. Casual employment in Australia, Australian Bulletin of Labour, 16(3): 156-173.

DUNLOP, Y. 2002. Low paid employment in Australia, PhD Thesis, Centre for Strategic Economic Studies, Victoria University of Technology.

ESPOSTO, A. 2011. Upskilling and polarisation in the Australian labour market: a simple analysis, Australian Bulletin of Labour, 37(2):191-216.

ESPOSTO, A. 2008. Dimensions of earnings inequality in the labour market: The Australia experience, VDM Verlag Dr Müller, Saarbrücken, Germany.

ESPOSTO, A. \& ABBOTT, M. 2011. A look at the long-term accumulation of human capital and knowledge intensity of work in Australia, Economic Papers, 30(3):414-430.

HAWKE, A. \& WOODEN, M. 1998, The changing face of Australian industrial relations. Economic Record, 74:74-88.

HOUGHTON, P. 2002. The global knowledge economy, Supporting Paper No.1, Centre for Strategic Economic Studies, Victoria University of Technology, Melbourne.

HOUGHTON, P. \& SHEEHAN,P. 2000. A primer on the knowledge economy, Working Paper 18, Centre for Strategic Economic Studies, Victoria University of Technology, Melbourne. Available at: http://www.cfses. com/documents/knowledgeeconprimer.pdf [accessed 2013-07-01].

MURTOUGH, G. \& WAITE, M. 2000. The growth of non-traditional employment: are jobs becoming more precarious? Staff Research Paper, Productivity Commission, Canberra.

ORGANISATION FOR ECONOMIC CO-PERATION AND DEVELOPMENT (OECD). 1996. The knowledge-based economy, OECD, Paris.

OWENS, R. 2001. The "Long-term or permanent casual" - An oxymoron or a "Well enough understood Australianism." Australian Bulletin of Labour, 27(2):118-136.

SALA-I-MARTIN, X. 2006. The world distribution of income: Falling poverty and convergence period, Quarterly Journal of Economics, 121(2):351- 397.

VANDENHEUVEL, A. \& WOODEN, M. 2000. Diversity in employment arrangements, in Mangan, J. (ed.) Understanding and reducing unemployment: National and state perspectives: 69-83, Office of Economic and Statistical Research, Queensland Treasury, Brisbane, 2000.

WATTS, R. 2001. The ACTU's response to the growth in long-term casual employment in Australia, Australian Bulletin of Labour, 27(2):137-149.

WOODEN, M. 2001. Are non-standard jobs sub-standard jobs, Australian Social Monitor, March, 3:65-70.

WOODEN, M. 2000. The changing skill composition of labour demand, Australian Bulletin of Labour, 26(3):191-198.

WOODEN, M. \& SLOAN, J. 1998. Industrial relations reform and labour market outcomes: A comparison of Australia, New Zealand and the United Kingdom, in Debelle, G. and Borland, J. (eds.) Unemployment and the Australian Labour Market, Reserve Bank of Australia, Sydney.

WOODEN, M. \& WARREN, D. 2003. The characteristics of casual and fixed-term employment: evidence from the HILDA survey, Melbourne Institute Working Paper no. 15/03, Melbourne Institute of Applied Economics and Social Research, University of Melbourne. 